Research Report

\title{
Effect of hydrogel Epigallocatechin-3-gallate (EGCG) to the number of fibroblast cell proliferation in the perforation of Wistar rat tooth pulp
}

\author{
Ira Widjiastuti, ${ }^{1}$ Setyabudi, ${ }^{1}$ Kun Ismiyatin, ${ }^{1}$ Djoko Agus Purwanto ${ }^{2}$ and Tiara Sukmawati ${ }^{1}$ \\ ${ }^{1}$ Department of Conservative Dentistry, Faculty of Dental Medicine, \\ ${ }^{2}$ Department of Pharmaceutical Chemistry, Faculty of Pharmacy, \\ Universitas Airlangga, Surabaya, Indonesia
}

\begin{abstract}
Background: Pulpitis can occur because the deep cavity preparation and it causes increasing of NO levels. Perforated teeth require direct pulp capping (DPC) treatment. The current standard DPC material is calcium hydroxide. However, several studies have found weaknesses of calcium hydroxide that can affect the success of DPC treatment and new, more biocompatible materials are needed. Epigallocatechin-3-gallate (EGCG) in green tea has many benefits, including antioxidant, anticolagenase, anticancer, anti-inflammatory and has the ability of radical scavenging to clean NO so that pulp healing can occur better by increasing the number of fibroblast cells that play a role in wound healing. Purpose: To determine the concentration of hydrogel EGCGs that are effective in increasing the number of fibroblast cell proliferation in the dental pulp perforation of Wistar rats. Methods: This research is a laboratory experimental study with a randomized post test only control group design. Samples used in the study were 24 male Wistar rats which were divided into four groups, namely the negative control group and the treatment group were given EGCG 60 ppm, 90 ppm, and 120 ppm and were decapitated on the $7^{\text {th }}$ day after treatment. The maxilla and the 1 st molar were taken and decalcified, to process the HPA reading with HE staining. Observations were made using a microscope with a magnification of 400x. Results: There were significant differences in the treatment groups with 60 ppm and 90 ppm hydrogel hydrogels on the results of the Oneway ANOVA difference test $(p<0.05)$. Conclusion: The concentration of hydrogel EGCG which is effective in increasing fibroblast cell proliferation is 90 ppm.
\end{abstract}

Keywords: Pulpitis; perforation; Epigallocatechin-3-gallate (EGCG); fibroblast.

Correspondence : Kun Ismiyatin, Department of Conservative Dentistry, Faculty of Dental Medicine, Universitas Airlangga, Mayjen. Prof. Dr Moestopo street 47, Surabaya, Indonesia, 60132. E-mail : kun-is@fkg.unair.ac.id.

\section{INTRODUCTION}

Pulpitis is an inflammation of the pulp tissue which can be caused by mechanical trauma, for example deep cavity preparation which causes damage in odontoblast layer. ${ }^{1}$ The friction and heat generated by using a bur when preparing deep cavities can cause the increased expression of nitric oxide (NO). NO is a free radical that is produced by the enzyme nitric oxide synthase (NOS). Free radicals play a role in inflammation and tissue damage. It can cause vasodilatation of bloodvessels so that inflammatory cells migrate from blood vessels to the tissues. ${ }^{2}$ With the inflammatory process, the healing process also occurs in the pulp. Fibroblast cells are commonly found in rich cell zone in the pulp. In the process of healing the pulp, transforming growth factor $\beta-1$ (TGF $\beta-1)$ and fibroblast growth factor (FGF) will stimulate fibroblast activity and proliferation of fibroblasts. ${ }^{3,4}$ In the process of reparative dentine formation, fibroblast cells play important roles as odontoblast like cells. ${ }^{5}$

Teeth that are perforated due to mechanical trauma require direct pulp capping (DPC) treatment. ${ }^{6}$ The current standard DPC material is calcium hydroxide. However, after research on calcium hydroxide can cause inflammation, pulp necrosis, and has soluble properties. Previous studies have shown that the failure rate of DPC treatment using $\mathrm{Ca}(\mathrm{OH}) 2$ is $13.64 \% .{ }^{7}$ Considering the weakness of calcium hydroxide, it is necessary to consider a new, more biocompatible material, namely epigallocatechin-3-gallate (EGCG) in green tea. EGCG has many benefits, including antioxidant, anticolagenase, anticancer, anti-inflammatory and has the ability of radical scavenging to clean NO. ${ }^{8}$

In this study EGCG was used in hydrogel form. Hydrogel have the ability to regulate drug release and protect drug content from the environment. ${ }^{9}$ In studies of in vitro biocompatibility hydrogel EGCG in fibroblast 
cell cultures with concentrations of $60 \mathrm{ppm}$ and $120 \mathrm{ppm}$ have been shown to have good biocompatibility because the percentage of living cells reaches $60 \%$. Based on these results, $60 \mathrm{ppm}, 90 \mathrm{ppm}$, and $120 \mathrm{ppm}$ concentrations were used to see the optimal concentration of EGCG in increasing the number of fibroblast cell proliferation in the pulp perforation of wistar rat teeth on the $7^{\text {th }}$ day. Based on previous research, fibroblast cells reached the highest number on the $7^{\text {th }}$ day after inflammation occurred. Giving EGCG in hydrogel form is expected to increase the number of fibroblast cell proliferation at the pulp perforation due to mechanical trauma so that the healing process of the pulp can run better. The aim of this research to determine the concentration of hydrogel EGCGs that are effective in increasing the number of fibroblast cell proliferation in the dental pulp perforation of Wistar rats.

\section{MATERIALS AND METHODS}

Ethical clearance was approved by the Ethical Eligibility Committee of the Dentistry Faculty, Universitas Airlangga (Number : 404/HRECC.FODM/VI/2019). This study was a laboratory in vivo experimental research with a randomized post test only control group design. The sample used in the study was 24 male Wistar rats (Rattus norvegicus) weighing 150-200 grams, aged 2-3 months, and the general condition of the good rats which were divided into four groups namely the control group (C), the maxillary first molar teeth of the experimental animals were prepared and perforated without hydrogel EGCG application; and three treatment groups which received cavity preparation and hydrogel EGCG application in 60 ppm (T1), 90 ppm (T2), and 120 ppm (T3) group.

EGCG in this study is the result of extraction from green tea with a concentration of $98 \%$ pure EGCG in the form of white powder (Xi 'An Rongseng Biotechnology Co., Ltd., Shaanxi, China). Hydrogel EGCG is made by mixing a hydrogel base and EGCG powder. Hydrogel base is made with Polyethylene glycol (PEG). PEG hydrogel is obtained by mixing $80 \%$ PEG 400 (Schuchardt OHG, Germany) with 20\% PEG 4000 (Sigma-Aldrich, St. Louis, USA; CAS Number:25322-68-3). Both are put into a porcelain cup and then melted with water bath. The melted PEG base is stirred homogeneously in a warm to half-cold mortar. After that, the EGCG extract was put into the base mixture and stirred until homogeneous. The concentrations of hydrogel EGCG used were $60 \mathrm{ppm}, 90 \mathrm{ppm}$ and $120 \mathrm{ppm}$.

The initial stage of the study was the adaptation of experimental animals by placing them in a prepared cage and covered with a lid of woven gauze, with a cage size of 60 $\mathrm{cm} \times 40 \mathrm{~cm}$ x $20 \mathrm{~cm}$. Each cage contains 4 Wistar rats. Wistar were adapted for 2 weeks at the Biochemical Laboratory of the Faculty of Medicine, Airlangga University, Surabaya. Each enclosure is labeled in the name of the treatment group. Rat food is given in small containers, twice a day every morning and evening at the same time every day. Rat drink is given in the form of water in a $300 \mathrm{ml}$ bottle equipped with a small pipe.

After the adaptation of experimental animals, treatment of experimental animals is carried out. Before cavity preparation, rats were anesthetized intramuscularly with $0.2 \mathrm{ml}$ of a mixture of $0.5 \mathrm{ml}$ of ketamine (Kepro B.V., Deventer, Holland) and 0.5 Xyla ${ }^{\circledR}$ xylazine base (PT. Tekad Mandiri, Bandung, Indonesia). The maxillary first molar was prepared on the occlusal surface using a diamond round bur with $0.8 \mathrm{~mm}$ in diameter Edenta ${ }^{\circledR}$ (Edenta corp, Switzerlannd) until pulp base (about $1.5 \mathrm{~mm}$ ), followed by a sonde until perforation, marked by bleeding and checked with Inline ${ }^{\circledR}$ paper points (B.M Dentale S.A.S, Torno, Italy). In the treatment group, hydrogel EGCG were applied on the tooth cavity that had been prepared. Hydrogel EGCG in 60 ppm concentration was applied with a TPC ${ }^{\circledR}$ micro brush (TPC Advances Tech.Inc,USA) on the basis of the cavity of the molar teeth of the T1 group. Hydrogel EGCG in 90 ppm and 120 ppm concentration also applied using a TPC ${ }^{\circledR}$ microbrush (TPC Advances Tech.Inc,USA) on the basis of the molar cavities of the T2 and T3 groups. Subsequently, the cavity was filled glass ionomer cement type II (Fuji 9, GC Corp, Tokyo, Japan) as a temporary restoration.

Seven days after treatment, the rats were decapitated and the maxilla and upper first molar tooth were taken. After that the rat is put in a container and buried in a place. The tissue were put into a fixation solution Polysciences ${ }^{\circledR}$ (Polysciences Inc, US) (10\% formalin buffer) for 1-2 x 24 hours at room temperature, followed by a decalcification process using 10\% EDTA solution $\mathrm{RPI}^{\circledR}$ (RPI Corp,USA) for \pm 30 days at room temperature, to soften the tissue. After that, a dehydration process is carried out on the specimens using alcohol in stages $(70 \%, 80 \%$, and $95 \%)$ for 1 hour each. The specimen is put into the alcohol : toluol solution in a ratio (1: 1), and followed by a purification process using pure toluol for 1 hour, then the specimen is put into a saturated paraffin toluol solution for 1 hour. After that the infiltration process is carried out into the $47^{\circ} \mathrm{C}$ oven for 1 hour by means of the specimen put in liquid paraffin and embedding the specimen and labeled / coded. After the embedding stage is completed, the tissue is sliced using a microtome with a thickness of $\pm 6 \mu \mathrm{m}$ transversely or in parallel with the long axis of the tooth. Then the piece is glued to the glass of the object that has been given meyer egg albumin.

To see fibroblast cells, Hematoxylin Eosin staining (HE) was did. Pulpal tissue preparations were included in xylol ( 5 minutes), then put in $100 \%, 90 \%, 80 \%$, and $70 \%$ absolute alcohol (3 minutes). Then the tissue preparation was washed with aquades $1 \mathrm{x}$ and with PBS pH 7.4 (3 x 5 minutes). After that it was stained with Mayer's Hematoxylin-Eosin (5 minutes) and washed with distilled water ( 3 x 5 minutes). The preparations are dried by aerating, mounting and covered with a glass cover and then observed under a light microscope with a magnification of $400 x$. 


\section{RESULTS}

At HE staining, fibroblasts will appear as spindle-shaped cells with a flat nucleus. The results of the calculation of the average number of fibroblast cells can be seen in the Table 1. The research data in the form of diagrams can be seen in the Figure 1.

Based on the data above, it can be seen that the higher the concentration of EGCG, the higher the average number of fibroblast cells present in the pulp tissue on the 7th day after treatment. After the data is obtained, data analysis is performed.

Based on the results of the one-way ANOVA test, it was found that there were significant differences between the number of fibroblasts in the control group with T2, and T3 and T1 with T2 and T3. However, there were no significant differences in the group control with T1 and T2 with T3.

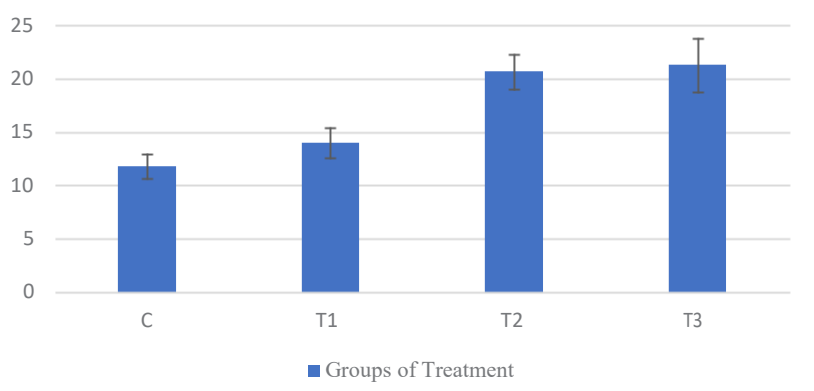

Figure 1. Diagram of Fibroblast Proliferation

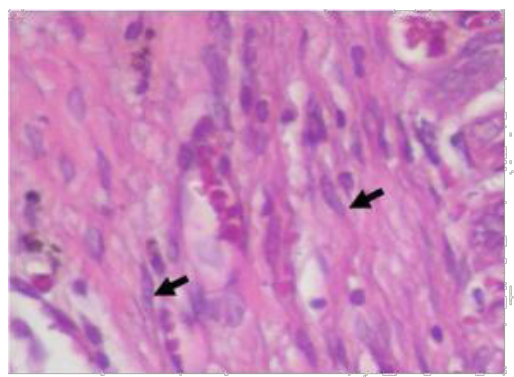

A

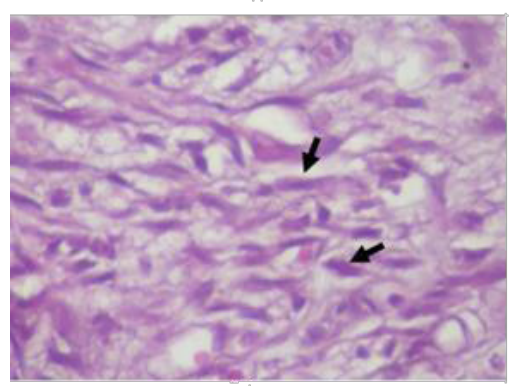

C
Table 1. Mean of fibroblast proliferation

\begin{tabular}{cccc}
\hline Group & $\mathrm{n}$ & Mean & $\begin{array}{c}\text { Standard } \\
\text { Deviation }\end{array}$ \\
\hline Control & 6 & 11.8 & 1.17 \\
Treatment 1 & 6 & 14 & 1.41 \\
Treatment 2 & 6 & 40.7 & 1.63 \\
Treatment 3 & 6 & 21.3 & 2.5 \\
\hline
\end{tabular}

$\overline{\text { Notes: Control (given injury without being treated); Treatment } 1}$ (given injury and treated with $60 \mathrm{ppm}$ hydrogel EGCG); Treatment 2 (given injury and treated with $90 \mathrm{ppm}$ hydrogel EGCG); Treatment 3 (given injury and treated with 120 ppm hydrogel EGCG).

Table 2. Test results of the one-way ANOVA and Tukey HSD

\begin{tabular}{|c|c|c|c|c|}
\hline & $\mathrm{C}$ & $\mathrm{T} 1$ & $\mathrm{~T} 2$ & $\mathrm{~T} 3$ \\
\hline $\mathrm{C}$ & & 0.175 & 0.000 & 0.000 \\
\hline T1 & & & 0.000 & 0.000 \\
\hline $\mathrm{T} 2$ & & & & 0.911 \\
\hline T3 & & & & \\
\hline
\end{tabular}

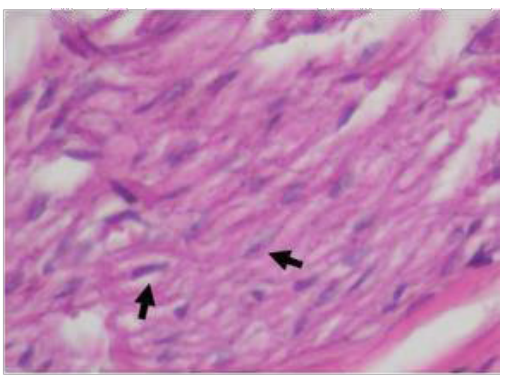

B

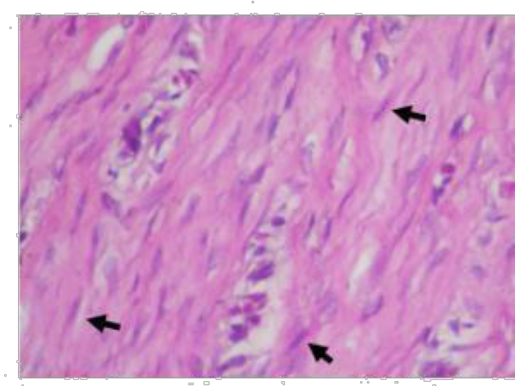

D

Figure 2. Photograph results of HPA examination of fibroblast cells on day $7: \mathrm{A}=\mathrm{Control}$ (given injury without being treated), $\mathrm{B}=$ T1 (given injury and treated with 60 ppm hydrogel EGCG), C = T2 (given injury and treated with 90 ppm hydrogel EGCG), $\mathrm{D}=\mathrm{T} 3$ (given injury and treated with $120 \mathrm{ppm}$ hydrogel EGCG). At the tip of the arrow are spindle-shaped fibroblast cells with a flat nucleus with 400x magnification. 


\section{DISCUSSION}

Fibroblasts are active cells when they respond to a wound by proliferating so that they become the main cells in the wound healing process. ${ }^{12}$ In the pulp, fibroblasts are in the most rich cell zone. 4 The results of this study prove that there are more fibroblast cells in the treatment group compared to control group and increase with increasing concentration of EGCG given. This proves the application of hydrogel EGCG can accelerate the pulp healing process through its antioxidant properties.

The antioxidant properties of EGCG mainly originate from the presence of hydroxyl groups or -OH groups which are easily oxidized in ring $\mathrm{B}$ and cause the opening of oxygen atoms so that they increase reactivity to biological polymeric bonds, bonds with heavy metals, catalyze electron transport, and capture free radicals. ${ }^{13,14} \mathrm{NO}$ which is a free radical is also captured by the -OH groups of EGCG. This results in vasoconstriction of blood vessels and decreased capillary permeability. As a result, there is a decrease in neutrophil cell migration into injury so that the acute phase of inflammation is more quickly completed. This stimulates macrophage activity as a second defense by increasing the number of macrophages to carry out the process of phagocytosis, clearing debris tissue, then releasing and activating growth factors such as platelet derived growth factor (PDGF), transforming growth factor $\beta$ (TGF $\beta$ ) and fibroblast growth factor (FGF) ) which stimulates the migration and proliferation of fibroblast cells. ${ }^{3}$

The number of fibroblast cells increases with increasing concentration of hydrogel EGCG applied. However, based on the analysis data there was an insignificant increase in the number of fibroblast cells in the control group with the T1 group. This could be due to the $-\mathrm{OH}$ group contained in the concentration of $60 \mathrm{ppm}$ which was not maximal in binding free radicals so that the number of fibroblasts formed had no difference significant number compared to the control group. Insignificant differences also occurred in T2 group and T3 group. This could be due to the presence of critical micelle concentration of hydrogel EGCG. Hydrogel EGCG concentration that are too high can increase the formation of micelles which results in reduced antioxidant properties so that the proliferation of fibroblast cells is not optimal. EGCG concentration of hydrogel that is too high can cause neutrophil infiltration migration so that it can inhibit fibroblast proliferation. ${ }^{15,16}$

\section{CONCLUSION}

Based on the research results and discussion above, it can be concluded that the effective concentration of hydrogel EGCG for increasing the number of fibroblast cell proliferation is $90 \mathrm{ppm}$.

\section{REFERENCES}

1. Nirwana I. Aktivitas Ekstrak Buah Delima (Punica granatum linn) Sebagai Material Pulp Capping terhadap Ekspresi IL-6, IL-10, TGFB-1, MMP-1, dan Kolagen Tipe I pada gigi Perforasi Mekanik. Universitas Airlangga; 2012: 1.

2. Fatimatuzzahro N, Heniastuti T, Handajani J. Respon inflamasi pulpa gigi tikus Sprague Dawley setelah aplikasi bahan etsa ethylene diamine tetraacetic acid 19\% dan asam fosfat 37\%. Dental Journal (Majalah Kedokteran Gigi). 2013;46(4):5.

3. Landén N, Li D, Ståhle M. Transition from inflammation to proliferation: a critical step during wound healing. Cellular and Molecular Life Sciences. 2016;73(20):3862.

4. Popowics T, Fehrenbach M. Illustrated dental embryology, histology, and anatomy. St. Louis (Mo.): Elsevier Saunders; 2016: 169

5. Kunarti S. TGF- $\beta 1$ as the Trigger of Pulp Fibroblast Proliferation. Folia Medica Indonesiana. 2008;44(2):67.

6. Torabinejad M, Walton R. Endodontics. 4th ed. Philadelphia, Pa.: Saunders; 2009: 49-54

7. Brizuela C, Ormeño A, Cabrera C, Cabezas R, Silva C, Ramírez V et al. Direct PulpCapping with Calcium Hydroxide, Mineral Trioxide Aggregate, and Biodentine in Permanent Young Teeth with Caries: A Randomized Clinical Trial. Journal of Endodontics. 2017;43(11):1776.

8. Chu C, Deng J, Man Y, Qu Y. Green Tea Extracts Epigallocatechin-3-gallate for Different Treatments. BioMed Research International. 2017;2017:1-3.

9. Ismiyatin K, Soetoyo A, Wahluyo S, Mukono I. Therapeutic Efficacy of Topical Epigallocatechin-Gallate as a New Therapeutic Strategy for Inhibition of Pain Conduction on Rat Models with Acute Pulpal Inflammation. International Medical Device and Technology Conference. 2017;:107110 .

10. Delicia D.Biokompatibilitas Epigallocatechin-gallate Dalam Gel polyethylene Glycol terhadap Sel Fibroblas Gingiva Manusia. Airlangga University; 2017: 43.

11. Kurnia PA, Ardhiyanto HB, Suhartini. Potensi ekstrak teh hijau (Camellia sinensis) terhadap peningkatan jumlah sel fibroblas soket pasca pencabutan gigi pada tikus Wistar. e-Jurnal Pustaka Kesehat. 2015; 3: 122-7.

12. Khan, S.; Hashmi, G. S. Histology and Functions of Connective Tissues: A Review Article. University J. Dent. Sci. 2015, 1, 1-2.

13. Legeay S, Rodier M, Fillon L, Faure S, Clere N. Epigallocatechin Gallate: A Review of Its Beneficial Properties to Prevent Metabolic Syndrome. Nutrients. 2015;7(7):5443-5468.

14. Sutini. Produksi Epigallocatechin Gallate Pada Kultur In Vitro Kalus Camellia Sinensis Sebagai Kandidat Pangan Fungsional. 2015;:92-100.

15. Kucera O, Mezera V, Moravcova A, Endlicher R, Lotkova H, Drahota $\mathrm{Z}$ et al. In VitroToxicity of Epigallocatechin Gallate in Rat Liver Mitochondria and Hepatocytes. Oxidative Medicine and Cellular Longevity. 2015;2015:2.

16. Wu Y, Choi H, Kang Y, Kim J, Shin J. In Vitro Study On AntiInflammatory Effects Of Epigallocatechin-3-Gallate-Loaded Nano- And Microscale Particles. International Journal of Nanomedicine. 2017;12:7007-7013. 